\title{
Article \\ Alkali-Activated Adsorbents from Slags: Column Adsorption and Regeneration Study for Nickel(II) Removal
}

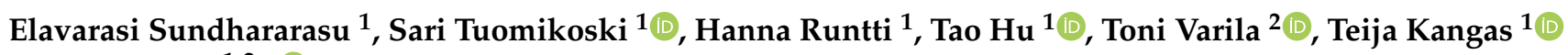 \\ and Ulla Lassi $1,2, *$ (1) \\ 1 Research Unit of Sustainable Chemistry, University of Oulu, P.O. Box 4300, 90570 Oulu, Finland; \\ elavarasi.sundhararasu@oulu.fi (E.S.); sari.tuomikoski@oulu.fi (S.T.); hanna.runtti@oulu.fi (H.R.); \\ tao.hu@oulu.fi (T.H.); teija.kangas@oulu.fi (T.K.) \\ 2 Unit of Applied Chemistry, Kokkola University Consortium Chydenius, University of Jyvaskylä, \\ Talonpojankatu 2B, FI-67100 Kokkola, Finland; toni.varila@chydenius.fi \\ * Correspondence: ulla.lassi@oulu.fi; Tel.: +358-400-294090
}

check for updates

Citation: Sundhararasu, E.; Tuomikoski, S.; Runtti, H.; Hu, T.; Varila, T.; Kangas, T.; Lassi, U.

Alkali-Activated Adsorbents from Slags: Column Adsorption and Regeneration Study for Nickel(II) Removal. ChemEngineering 2021, 5, 13. https://doi.org/10.3390/ chemengineering5010013

Academic Editor: Alírio E. Rodrigues

Received: 5 February 2021

Accepted: 1 March 2021

Published: 5 March 2021

Publisher's Note: MDPI stays neutral with regard to jurisdictional claims in published maps and institutional affiliations.

Copyright: (c) 2021 by the authors. Licensee MDPI, Basel, Switzerland. This article is an open access article distributed under the terms and conditions of the Creative Commons Attribution (CC BY) license (https:// creativecommons.org/licenses/by/ $4.0 /)$.

\begin{abstract}
Alkali-activated adsorbents were synthesized by mixing three different slags from the steel industry: blast furnace slag (BFS), ladle slag (LS), and Lintz-Donawitz converter slag (LD). These powdered slag-based geopolymers (GP) were used to remove nickel(II) from aqueous solutions in fixed-bed column studies. The experiments were conducted in $\mathrm{pH} 6$ using a phosphate buffer with initial nickel(II) concentration of $50 \mathrm{mg} / \mathrm{L}$. Samples were taken at time intervals of between 5 and $90 \mathrm{~min}$. Three adsorption-desorption cycles were implemented with a flow rate of $5 \mathrm{~mL} / \mathrm{min}$. The geopolymers were characterized by Fourier-Transform Infrared Spectroscopy (FTIR), X-ray powder diffraction (XRD), Field Emission Scanning Electron Microscopy (FESEM), X-ray fluorescence (XRF), specific surface area measurements, and a leaching test. The data were found to describe the Thomas, Adams-Bohart, and Yoon-Nelson models well. For GP (BFS, LS), experimental adsorption capacity was $2.92 \mathrm{mg} / \mathrm{g}$, and for GP (LD, BFS, LS), it was $1.34 \mathrm{mg} / \mathrm{g}$. The results indicated that the produced adsorbents have the potential to be used as adsorbents for the removal of nickel(II).
\end{abstract}

Keywords: column studies; wastewater treatment; heavy metal; kinetic models

\section{Introduction}

The growth of an industrial society depends on water. However, untreated industrial wastewater is harmful to the environment as it includes substances such as heavy metals. Heavy metal in wastewater is caused by various industrial sectors, including battery industry, electroplating, and printed circuit board manufacturing companies [1]. The toxicity of heavy metals can endanger life forms; thus, it is essential to remove them to avoid damaging the environment [2]. However, the methods used for removing heavy metals out of wastewater (such as chemical precipitation, ion exchange, reverse osmosis, and solvent extraction) have some disadvantages, including high investment and operational costs and the ensuing disposal of residual metal sludges [3]. Due to its simplicity and effectiveness, adsorption has recently become a popular research approach in wastewater treatment. It is a suitable technology for use in the removal of heavy metals such as chromium $(\mathrm{Cr})$, cadmium $(\mathrm{Cd})$, lead $(\mathrm{Pb})$, zinc $(\mathrm{Zn})$, copper $(\mathrm{Cu})$, nickel $(\mathrm{Ni})$, arsenic (As), and mercury (Hg) $[1,3-7]$.

In addition to virgin materials, industrial by-products have potential to be used as a raw material for low-cost adsorbents that can be used for the remediation of heavy metal-contaminated wastewaters. In optimum cases, these materials require only minor processing to enhance their adsorptive capacities. Due to their abundance, availability, and high performance, they are considered better alternatives than the most common adsorbent, activated carbon [3]. Due to their porous structure and low cost, alkali-activated adsorbents 
are currently being widely applied for wastewater treatment. Moreover, alkali-activated materials have great potential to be used as commercial adsorbents [8-11].

Alkali-activated adsorbents are abbreviated to geopolymers in this paper, even though the structure and formation may not be fully geopolymerized. Geopolymers are basically inorganic polymer materials derived from the alkali activation of aluminosilicate materials, such as fly ash [12], blast furnace slag (BFS) [13], metakaolin [14], Lintz-Donawitz converter slag (LD) [15], and granulated blast furnace slag [16]. Commonly used alkali activators in the synthesis of geopolymers include sodium and potassium hydroxide or sodium and potassium silicate [17]. Alkali-activated materials produced from industrial side streams are a cost-effective solution for the adsorption of heavy metals such as $\mathrm{Cd}, \mathrm{Ni}$, boron (B), fluoride $\left(\mathrm{F}^{-}\right)$, phosphate $\left(\mathrm{PO}_{4}{ }^{-3}\right), \mathrm{NOx}$, and dyes [18]. Alkali-activated materials have a heterogeneous microstructure, amorphous structure, and possess good surface properties for adsorption. In wastewater purification process, the structure of the porous, adjustable nature and the negative charge on aluminum play an important role $[1,2,19]$. The capacity of alkali-activated materials to attract cations is due to the presence of charge imbalance caused by aluminum in the structure [2].

In this paper, the nickel removal over industrial by-product-based adsorbents is studied. Nickel is a heavy metal with several effects on human health because it causes chronic bronchitis, reduced lung function, and cancer of the lungs. Moreover, the extensive industrial use of nickel means that a considerable amount of it can enter the aquatic life environment through wastewater discharge. If nickel levels are above the permissible range, its ingestion is associated with the inhibition of oxidative enzyme activity, which can cause several issues to life forms [16,20-22]. Industrial activities such as electronics equipment manufacturing and metal cleaning often discharge high concentrations of nickel ions into the wastewater, causing serious water pollution. Since the presence of nickel ions above critical levels may affect the life forms, it is essential that they are removed [23].

Currently, a limited number of studies have addressed the use of alkali-activated materials for nickel(II) removal from aqueous solutions [13,14]. Accordingly, this research investigates the removal of nickel(II) from wastewater using an alkali-activated adsorbent and the column method. There is also a lack of study in the area of using slags from the steel industry (especially ones other than blast furnace slag) for geopolymerization. However, this study fulfills these knowledge gaps. In addition, many adsorption studies on the removal of metals have been performed using batch experiments [12,24]. In this study, the experiments in column have been implemented. This is advantageous because the scalability of results to a larger scale is easier than with batch experiments. Different raw materials intended to be used to prepare geopolymers, including the optimization of the preparation steps and the usage of the produced adsorbents for nickel(II) ions, have been studied in this research.

To characterize the adsorbent, X-ray fluorescence (XRF), X-ray powder diffraction (XRD), Field Emission Scanning Electron Microscope (FESEM), Brunauer-Emmett-Teller (BET), Fourier transform infrared spectra (FTIR), and leaching tests were used. Kinetic models suitable for column studies were applied. This research aims to propose a costeffective, environment-friendly, and efficient material for separating nickel(II) from aqueous solutions using slag-based alkali-activated adsorbents, resulting in the purification of wastewater. Three cycles of adsorption and desorption regeneration were performed for the reusability of the packed column.

\section{Materials and Methods}

\subsection{Materials}

Blast furnace slag (BFS), ladle slag (LS), and Lintz-Donawitz converter slag (LD), obtained from a SSAB Europe's production site located in Raahe, Finland, were used as raw materials for geopolymerization. BFS is a by-product of smelting iron in a blast furnace, LD slag is generated in a Lintz-Donawitz converter in steel plants, and ladle slag (LS) is formed 
during the ladle treatment process stage in steel plants during smelting. The detailed compositions of these raw materials are presented in the Results and Discussion Sections.

For the synthesis of geopolymer, sodium silicate (VWR International, Radnor, PA, USA) and Sodium hydroxide (VWR International) were used, and sodium hydroxide solution (FF Chemicals, Werkendam, The Netherland) and hydrochloric acid solution (FF Chemicals) were used to adjust the $\mathrm{pH}$ value. Nickel(II) sulfate hexahydrate (Merck, Kenilworth, NJ, USA) was used in the preparation of synthetic wastewater, nitric acid (Merck) was used for acid washing of glassware, and a phosphate buffer (FF chemicals) was used to maintain the $\mathrm{pH}$ range.

\subsection{Synthesis of Geopolymer (GP)}

The BFS, LS, and LD slags were sieved to a particle size of $<1 \mathrm{~mm}$. The alkaline solution was prepared by mixing sodium silicate solution with $10 \mathrm{M}$ sodium hydroxide using a 1:1 weight ratio over the duration of $24 \mathrm{~h}$ by shaking in a magnetic stirrer. To form colloid paste, the powdered slag mixtures $(<1 \mathrm{~mm})$ with 1:1 weight ratio were mixed along with an alkaline solution with 3:2 weight ratio and then the prepared colloid was discharged into a polyethylene silicon mold and kept at room temperature for 3 days. Slag-based geopolymer was crushed using a jaw crusher and sieved to $<0.150 \mathrm{~mm}$. The sieved geopolymer was then washed with distilled water to remove excess alkaline solution and dried in an oven at $105^{\circ} \mathrm{C}$ for $24 \mathrm{~h}$. GP (BFS, LS) was prepared by mixing powdered blast furnace slag and ladle slag $w / w 1: 1$ with alkaline solution $w / w 3: 2$, and GP (LD, BFS, LS) was prepared by mixing powdered LD slag, BFS, and LS slag $w / w$ 1:2:1 with alkaline solution $w / w$ 3:2.

\subsection{Methods of Characterization}

Surface areas were determined by a BET isotherm (Micromeritics ASAP 2020 instrument). The bonding behavior and surface analysis were analyzed by FTIR using a Perkin Elmer Spectrum One spectrometer. The microstructure and external surface were analyzed by a Zeiss Sigma FESEM at the Centre for Material Analysis in the University of Oulu. Elemental composition was determined by using an XRF spectrometer (PANalytical Axios $\mathrm{mAX}$ ) and nickel concentrations were analyzed by using Atomic absorption spectroscopy (PerkinElmer A Analyst 200, Waltham, MA, USA). The powdered diffraction patterns were analyzed by a PANalytical X'pert Pro X-ray diffractometer using monochromatic CuK $\alpha 1$ radiation $(\lambda=1.5406 \AA)$ at $45 \mathrm{kV}$ and $40 \mathrm{~mA}$. The diffractograms were collected in the $2 \theta$ range of $10^{\circ}$ to $85^{\circ}$ at $0.017^{\circ}$ intervals and with a scan step time of $90 \mathrm{~s}$. The crystalline phases and structures were analyzed by HighScore Plus software. Chemical stability was studied using a leaching test, performed with a ratio of 1:10 using slag-based geopolymer and distilled water. The stabilities of the geopolymers were estimated by measuring the $\mathrm{pH}$ value and conductivity with different shaking time intervals from $30 \mathrm{~min}$ to $24 \mathrm{~h}$.

\subsection{Nickel(II) Removal with Powdered Slag-Based Geopolymer: Column Experiments}

The fixed-bed column was designed by using a plastic column (height: $7 \mathrm{~cm}$, inner diameter: $3.3 \mathrm{~cm}$ ) connected with a peristaltic pump (Watson-Marlow 120 Series). A plastic sieve was placed at the bottom of the column. A thin layer of glass wool and $5 \mathrm{~g}$ of acid-washed fine sand was placed on the sieve to avoid any loss of adsorbents. Three grams of fine $(<0.150 \mathrm{~mm})$ adsorbent was used in the column experiments. Further, $12 \mathrm{~g}$ of acid-washed fine sand and $58 \mathrm{~g}$ of acid-washed normal sand were used before and after the adsorbent layers. To avoid chemical precipitation, $\mathrm{pH} 6$ was used in the pretest, which was found to be optimum compared to $\mathrm{pH} 2$ and 4. Synthetic nickel(II) solution with a concentration of $50 \mathrm{mg} / \mathrm{L}$ was prepared from $1 \mathrm{~g} / \mathrm{L}$ stock solution by diluting with phosphate buffer solution to maintain the $\mathrm{pH}$ at 6 during adsorption experiments.

Nickel(II) concentrations were analyzed by using atomic absorption spectroscopy, and the samples were taken before and after experiments and within different time intervals. The experiment was stopped after $90 \mathrm{~min}$, and the column was washed with distilled water. Regeneration experiments were conducted using the mixture of $0.2 \mathrm{M}$ of $\mathrm{NaCl}$ and 
$0.1 \mathrm{M} \mathrm{NaOH}$ with a weight ratio 3:1 (w/w) using the same flow rate of $5 \mathrm{~mL} / \mathrm{min}$ as in the first cycle. After regeneration, the column was also washed with distilled water. Three adsorption-regeneration cycles were completed.

The adsorption column capacity is $q_{\text {total }}(\mathrm{mg})$, and $C_{a d}\left(C_{a d}=C_{0}-C_{t}\right)(\mathrm{mg} / \mathrm{L})$ is the outflow time $(t, \mathrm{~min})$, in which $C_{0}$ and $C_{t}$ represent the initial and final concentration values of the nickel(II) solution, respectively.

These values are calculated using Equation (1) as follows:

$$
q_{\text {total }}=\frac{Q A}{1000}=\frac{Q}{1000} \int_{t=0}^{t=t_{\text {total }}} C_{a d} d t
$$

In Equation (1), $t_{\text {total }}$ refers to the total residual time (min), $Q$ to the outflow rate $(\mathrm{mL} / \mathrm{min})$, and the area below the breakthrough curve is referred to as $A$. The equilibrium metal uptake in the column which shows the saturation loading capacity of the used adsorbent bed, $q_{e q}(\mathrm{mg} / \mathrm{g})$, can be calculated by Equation (2) as follows:

$$
q_{\text {eq }}=\frac{q_{\text {total }}}{m},
$$

where $m$ is the total dry weight (g) of slag-based geopolymer GP (BFS, LS) or GP (LD, BFS, LS) in the column.

\subsection{Kinetic Models}

For an effective column adsorption process, it is necessary to predict the concentrationtime profile or breakthrough curve for effluent parameters. However, few mathematical models have been developed for use in the design of continuous fixed adsorption columns. To predict the breakthrough curve behavior, Adams-Bohart, Thomas, and Yoon-Nelson models were applied in this work.

\subsubsection{Adams-Bohart Model}

The Adams-Bohart model was used to formulate the equation which shows the relation between $\frac{C_{t}}{C_{0}}$ and $t$ in a flowing system, which was done for the adsorption of chlorine on charcoal. The Adams-Bohart model assumes that both the adsorbing species' concentration and the adsorbent's residual capacity are proportional to the rate of the adsorption [25]. To calculate the initial part of the breakthrough curve, the Adams-Bohart model is used and the observed mass transfer rates comply with the following Equation (3):

$$
\ln \frac{C_{t}}{C_{0}}=k_{A B} C_{0} t-k_{A B} N_{0} \frac{Z}{F} .
$$

In Equation (3), $k_{A B}$ refers to the kinetic constant (L/mg min), $F$ indicates the linear flow rate $(\mathrm{cm} / \mathrm{min}), N_{0}$ is the saturation unit $(\mathrm{mg} / \mathrm{L})$, and $Z$ refers to bed height $(\mathrm{cm})$. Terms $C_{0}$ and $C_{t}$ are the inlet and effluent nickel(II) ion concentrations (mg/L), respectively. This model is widely used to predict adsorption in a column system and is based on the surface-reaction-rate theory $[21,26]$.

\subsubsection{Thomas Model}

The Thomas model is used for column adsorption processes to determine the breakthrough curve of the outflow. This also requires the maximum adsorption capacity of an adsorbent. The Thomas model can be expressed in the following equation:

$$
\ln \left(\frac{C_{0}}{C_{t}}-1\right)=\frac{k_{T h} q_{0} w}{Q}-k_{T h} C_{0} t
$$

In Equation (4), $k_{T h}(\mathrm{~L} / \mathrm{min} \mathrm{mg})$ is the kinetic coefficient and $q_{0}(\mathrm{mg} / \mathrm{g})$ is the adsorption capacity of the bed. The adsorption capacity of the bed at a given flow rate can be calculated from a plot of $\ln \left[\left(C_{0} / C_{t}\right)-1\right]$ against $t$ [27]. This model has the assumption of 
Langmuir kinetics of adsorption-desorption and it is a widely used method in column performance theory. The driving force rate complies with the second-order reversible reaction kinetics and adsorption does not have any axial dispersion derived. Generally, adsorption is not limited by chemical reaction kinetics. However, it is frequently controlled by interphase mass transfer. This issue can result in some errors when this method is used to model adsorption processes [21,26].

\subsubsection{Yoon and Nelson Model}

The Yoon and Nelson model is used to investigate the breakthrough behavior of adsorbate on adsorbent. This model assumes that the probability of the adsorbate breakthrough on the adsorbent and the adsorbate adsorption are proportional to the rate of the decrease in the probability of adsorption of each adsorbate molecule [28]. This model is less complicated than the other models and needs no detailed data, such as the adsorbate characteristics or adsorbent's type or properties of the adsorption bed. The following shows the equation for a single component system in the Yoon and Nelson model:

$$
\ln \frac{C_{t}}{C_{0}-C_{t}}=k_{Y N} t-\tau k_{Y N},
$$

where $k_{Y N}$ refers to the rate constant $(\mathrm{L} / \mathrm{min})$ and $\tau$ shows the time required for $50 \%$ of the adsorbate breakthrough ( $\mathrm{min}$ ), and $t$ is the breakthrough time (min). The Yoon-Nelson model does not require the characteristics of the adsorbate and adsorbent or the parameters of the column system $[21,26]$.

\section{Results and Discussion}

\subsection{Characteristics of Slag-Based Geopolymers}

Table 1 presents the elemental compositions of the raw materials of BFS, LS, and LD slags, as analyzed by XRF. The components of all the slags were mainly calcium oxide, aluminum oxide, magnesium oxide, and silica.

Table 1. X-ray fluorescence (XRF) results of raw materials blast furnace slag (BFS), ladle slag (LS), and Lintz-Donawitz converter slag (LD).

\begin{tabular}{cccc}
\hline Composition (\%) & BFS & LS Slag & LD Slag \\
\hline $\mathrm{Al}_{2} \mathrm{O}_{3}$ & 8.42 & 27.9 & 1.5 \\
$\mathrm{SiO}_{2}$ & 27.20 & 11.2 & 14.6 \\
$\mathrm{~K}_{2} \mathrm{O}$ & 0.55 & 0.13 & 0.08 \\
$\mathrm{CaO}$ & 38.47 & 43.2 & 46.4 \\
$\mathrm{Fe}$ & - & 1.38 & 13.9 \\
$\mathrm{FeO}_{3}$ & 0.78 & - & - \\
$\mathrm{TiO}_{2}$ & 1.28 & - & - \\
$\mathrm{Ti}$ & - & 0.46 & 0.47 \\
$\mathrm{MgO}_{\mathrm{SO}}$ & 9.39 & 6.1 & 1.5 \\
$\mathrm{~S}$ & 3.76 & - & - \\
$\mathrm{Mn}$ & - & 0.25 & 0.08 \\
$\mathrm{Na}_{2} \mathrm{O}$ & 0.26 & 0.69 & 1.8 \\
& 0.03 & 0.11 & 0.09 \\
\hline
\end{tabular}

The ratio of aluminosilicates $\left(\mathrm{Al}_{2} \mathrm{O}_{3}\right.$ and $\left.\mathrm{SiO}_{2}\right)$ affects the geopolymerization [29-31]. Since LD slag contains low amounts of aluminum and some amount of silicon, and LS slag contains much aluminum and some amount of silicon, BFS slag needs to be mixed for geopolymers to justify the $\mathrm{Si} / \mathrm{Al}$ ratio so that the amount of silicon is higher compared to aluminum. The main components confirm the suitability of raw materials for geopolymer production. The specific BET surface areas were obtained as 33 and $69.5 \mathrm{~m}^{2} / \mathrm{g}$ for GP (BFS, LS) and GP (LD, BFS, LS), respectively. Geopolymers typically act as ion exchangers, in which the specific surface area does not play an important role. However, these 
results indicate that the material surface area is also enabling adsorption in addition to ion exchange. Luukkonen et al. (2016) [13] reported specific surface area of $64.5 \mathrm{~m}^{2} / \mathrm{g}$ for BFS-based geopolymer and $22.4 \mathrm{~m}^{2} / \mathrm{g}$ for metakaolin-based geopolymer. Sarkar et al. (2017) [15] reported specific surface area of $30.84 \mathrm{~m}^{2} / \mathrm{g}$ for geopolymer prepared from LD slag. Mácová et al. (2020) [32] reported $19.8 \mathrm{~m}^{2} / \mathrm{g}$ total pore area for metakaolin-based geopolymers. Therefore, the surface area of sample prepared in this study, GP (LD, BFS, LS), was higher than the surface area of geopolymers presented in the literature. Further, the surface area of the sample GP (BFS, LS) prepared in this study was higher compared with metakaolin-based geopolymers but lower than BFS-based geopolymer. There is a variation in the surface area of the geopolymer depending on whether it is slag- or mixed slag-based. The higher surface area and pore volume of the geopolymer resulted in a variation of adsorption capacity $[19,33]$.

The X-ray diffraction patterns of raw materials LD slag, LS slag, and BFS are presented in Figure 1. The observed peaks were identified in the crystalline phase according to the International Centre for Diffraction Data (ICDD) (PDF-4+2020) using the HighScore Plus program in the raw materials of the LS, LD slag, and BFS. From Figure 1, the XRD pattern of LD slag, the peaks with most higher intensities at $2 \theta$ of $18.0^{\circ}, 28.6^{\circ}, 34.0^{\circ}, 47.1^{\circ}, 50.7^{\circ}, 54.3^{\circ}$, $64.17^{\circ}$, and $71.68^{\circ}$ were matched with the portlandite $\mathrm{Ca}(\mathrm{OH})_{2}(\mathrm{ICDD} 00-004-0733)$. Peaks with $2 \theta$ of $29.3^{\circ}$ and $42.80^{\circ}$ were matched with calcite $\mathrm{CaCO}_{3}$ (ICDD 04-007-8659). Peaks with $2 \theta$ of $32.4^{\circ}$ and $41.03^{\circ}$ were matched with calcium silicate $\mathrm{Ca}_{2} \mathrm{SiO}_{4}$ (ICDD 00-0060476). The peaks with $2 \theta$ of $33.4^{\circ}$ and $46.6^{\circ}$ were matched with calcium magnesium iron silicate $\mathrm{Ca}_{2} \mathrm{Fe}_{1.2} \mathrm{Mg}_{0.4} \mathrm{Si}_{0.4} \mathrm{O}_{5}$ (ICDD 00-045-0571). The small peak at $2 \theta$ of $30.9^{\circ}$ matched with ankerite (ICDD 00-012-0088). For LS slag, the katoite $(\mathrm{CaO})_{3} \mathrm{Al}_{2} \mathrm{O}_{3}\left(\mathrm{H}_{2} \mathrm{O}\right)_{6}(\mathrm{ICDD} 01-$ 072-1109), calcio-olivine $\mathrm{Ca}_{2} \mathrm{SiO}_{4}$ (ICDD 00-049-1672), grossular $\mathrm{Ca}_{3} \mathrm{Al}_{2}\left(\left(\mathrm{SiO}_{4}\right)_{1.8}\left(\mathrm{O}_{4} \mathrm{H}_{4}\right)_{1.2}\right)$ (ICDD 01-083-7409), and str $\delta$ tlingite $\mathrm{Ca}_{2} \mathrm{Al}_{2} \mathrm{SiO}_{7} \cdot 8 \mathrm{H}_{2} \mathrm{O}$ (ICDD 00-029-0285) were identified according to the HighScore analysis. The XRD pattern of BFS showed that mainly amorphous structure is presented because there is a broad halo at the $2 \theta$ of $20-40^{\circ}$, which is typical for amorphous. When checking the halo closely, one can find a tiny peak at $2 \theta$ of $29.3^{\circ}$ which matched $\mathrm{CaCO}_{3}$ (ICDD 01-071-3699).

Calcium carbonate (ICDD 01-071-3699) and katoite (ICDD 01-077-0240) were identified as major peaks after geopolymerization for GP (BFS, LS) and GP (LD, BFS, LS) (Figure 2). This confirms the crystalline and amorphous phases in GP (BFS, LS) and GP (LD, BFS, LS). In the X-ray diffraction analysis, there were no peaks for silicates or aluminum silicates for these two GP samples. Further, the above peaks confirm the possible presence of aluminum and silicon, as an amorphous phase or crystalline structure was found below the detection limit.

Figure 3 shows the FTIR spectra of the geopolymers and nickel(II)-loaded geopolymers that were obtained in the range $650-3500 \mathrm{~cm}^{-1}$. The peak appearing at $871-957 \mathrm{~cm}^{-1}$ corresponded to the presence of the $\mathrm{Si}-\mathrm{O}-\mathrm{Si}(\mathrm{Al})$ asymmetric stretch band (Luukkonen et al., 2016) [13]. This shows that a geopolymer structure exists in the produced material. The highest peak at $957 \mathrm{~cm}^{-1}$ shifted to 1009 and $1023 \mathrm{~cm}^{-1}$ in the spectra of nickel(II)-loaded GP (BFS, LS) and GP (LD, BFS, LS) that is typical in cases of metal ion adsorption [14]. At wave number $1411-1432 \mathrm{~cm}^{-1}$, the peaks can be attributed to carbon dioxide $(\mathrm{O}-\mathrm{C}-\mathrm{O})$ that may indicate carbonate structure. The source of carbon dioxide is atmospheric $[15,34]$. The weak peaks at $1647-1651 \mathrm{~cm}^{-1}$ can be ascribed to the $\mathrm{H}-\mathrm{OH}$ bonding in water [15], indicating that water binded to the geopolymer structure. After adsorption, two new peaks formed at 1200 and $1316 \mathrm{~cm}^{-1}$, indicating the presence of the $\mathrm{Si}-\mathrm{O}-\mathrm{Al}$ asymmetric stretch mode [35]. 


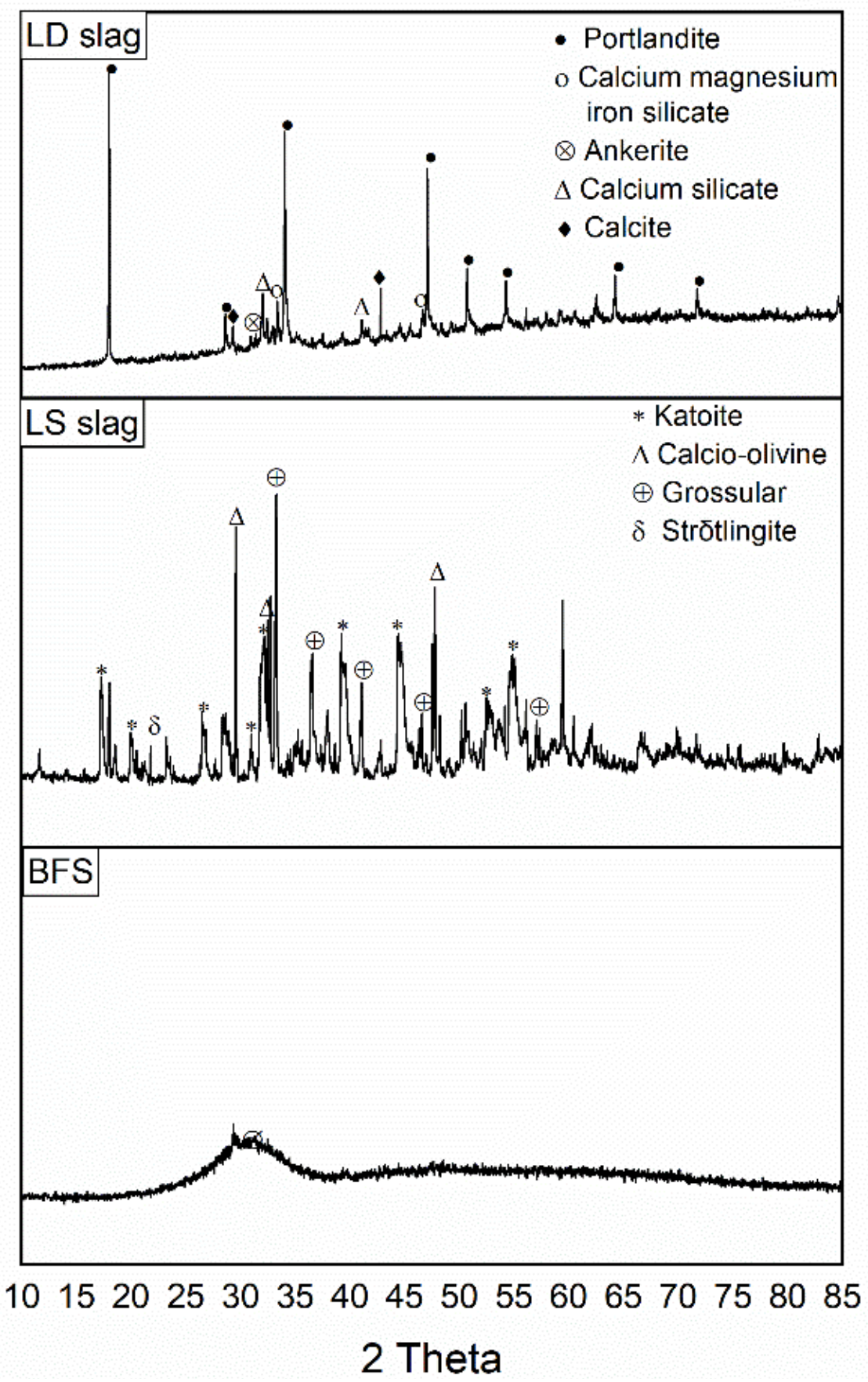

Figure 1. X-ray diffraction (XRD) pattern of raw materials LD slag, LS slag, and BFS. 


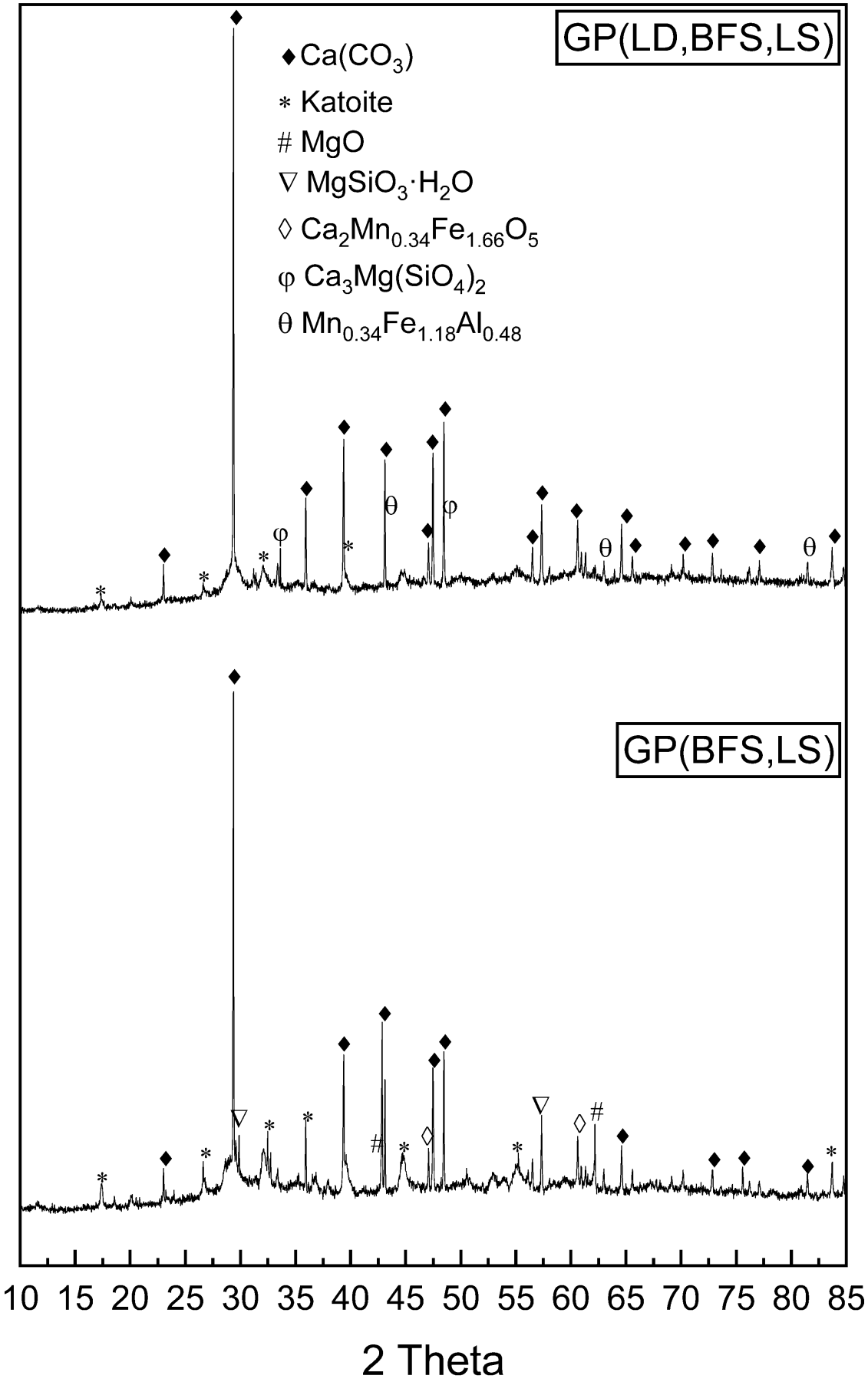

Figure 2. XRD patterns of geopolymers GP (BFS, LS) and GP (LD, BFS, LS). 


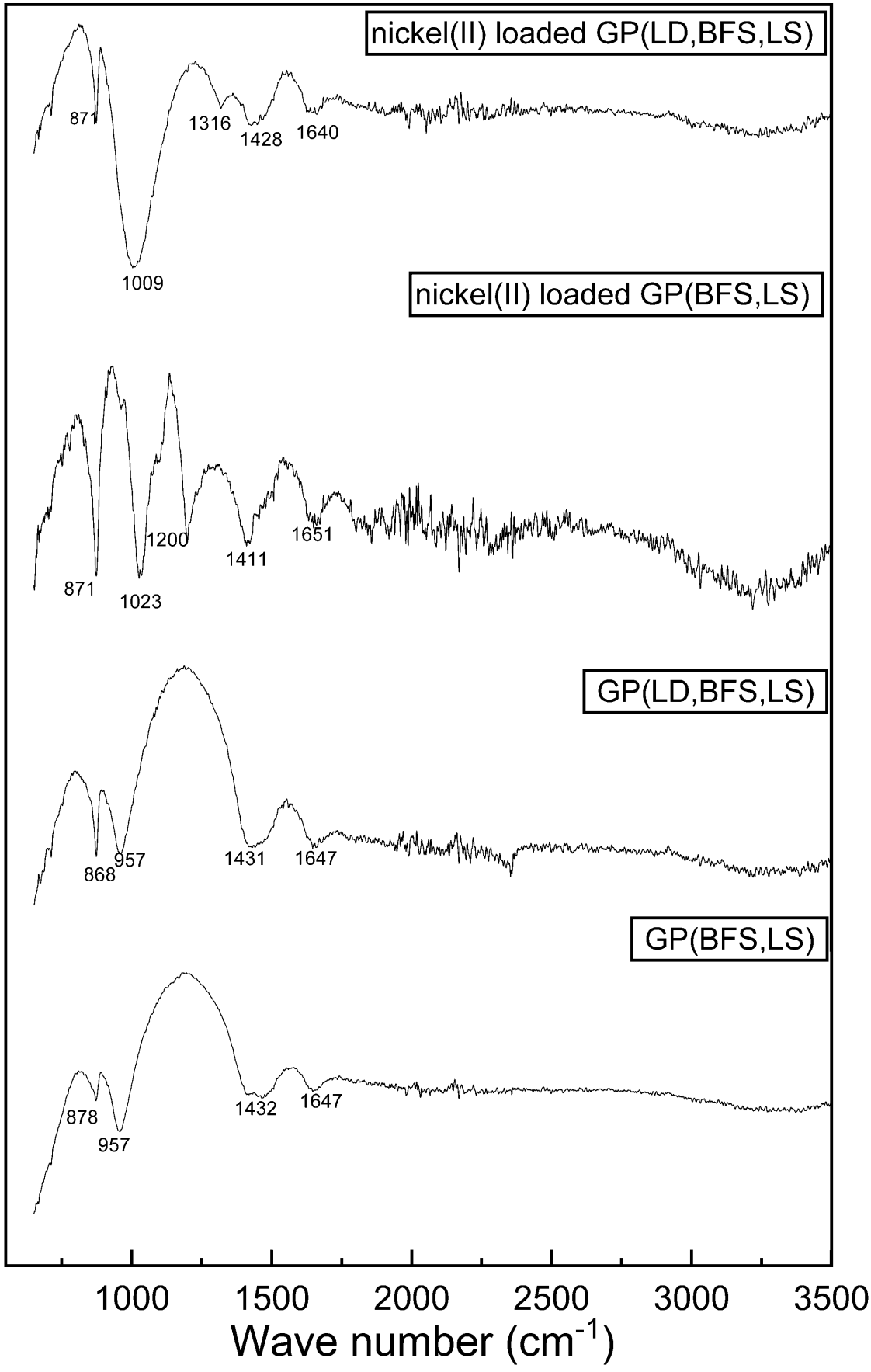

Figure 3. Fourier transform infrared (FTIR) spectra of GP (BFS, LS), GP (LD, BFS, LS), nickel(II) loaded GP (BFS, LS), and nickel(II) loaded GP (LD, BFS, LS).

The slag-based geopolymers GP (BFS, LS) and GP (LD, BFS, LS) were also imagined by FESEM. Figure 4 shows that geopolymers have a crystalline surface structure due to alkaline activation occurring on the slag surface. This structure is confirmed to have sufficient pores for carrying out the adsorption methods. 

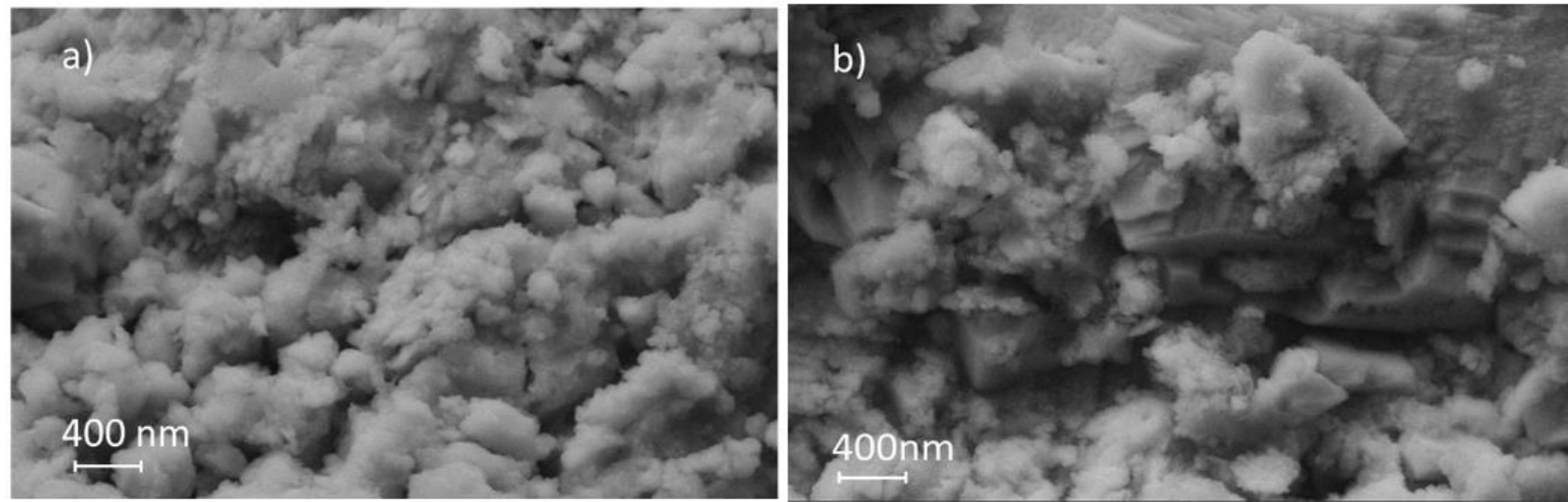

Figure 4. Field Emission Scanning Electron Microscope (FESEM) images of the slag-based geopolymer (a) GP (BFS, LS) and (b) GP (LD, BFS, LS).

\subsection{Leaching Test for Stability}

Stability tests were implemented according to Aly et al. (2008) [36] and Lancellotti et al. (2010) [37]. Washed and dried slag-based geopolymer $(<0.150 \mathrm{~mm})$ and distilled water in a ratio of 1:10 was placed in the Falcon tube and shaken with a laboratory shaker for $24 \mathrm{~h}$. The $\mathrm{pH}$ value and conductivity were measured after $24 \mathrm{~h}$ leaching time. Geopolymers with different receipt were prepared and the stability was checked by a leaching test. A slight gradual increase in conductivity for geopolymers (GP (BFS, LS) and GP (LD, BFS, $\mathrm{LS})$ ) during the $24 \mathrm{~h}$ of leaching time indicates a slight release of ions into solution. Figure 5 shows conductance and $\mathrm{pH}$ values for the samples (GP (BFS, LS) and GP (LD, BFS, LS)), in which samples were taken at time intervals from $30 \mathrm{~min}$ to $24 \mathrm{~h}$. As can be seen in Figure 5, geopolymers are alkaline materials; therefore, adsorption experiments were conducted in buffer solution to maintain the selected $\mathrm{pH}$ value during the experiment.
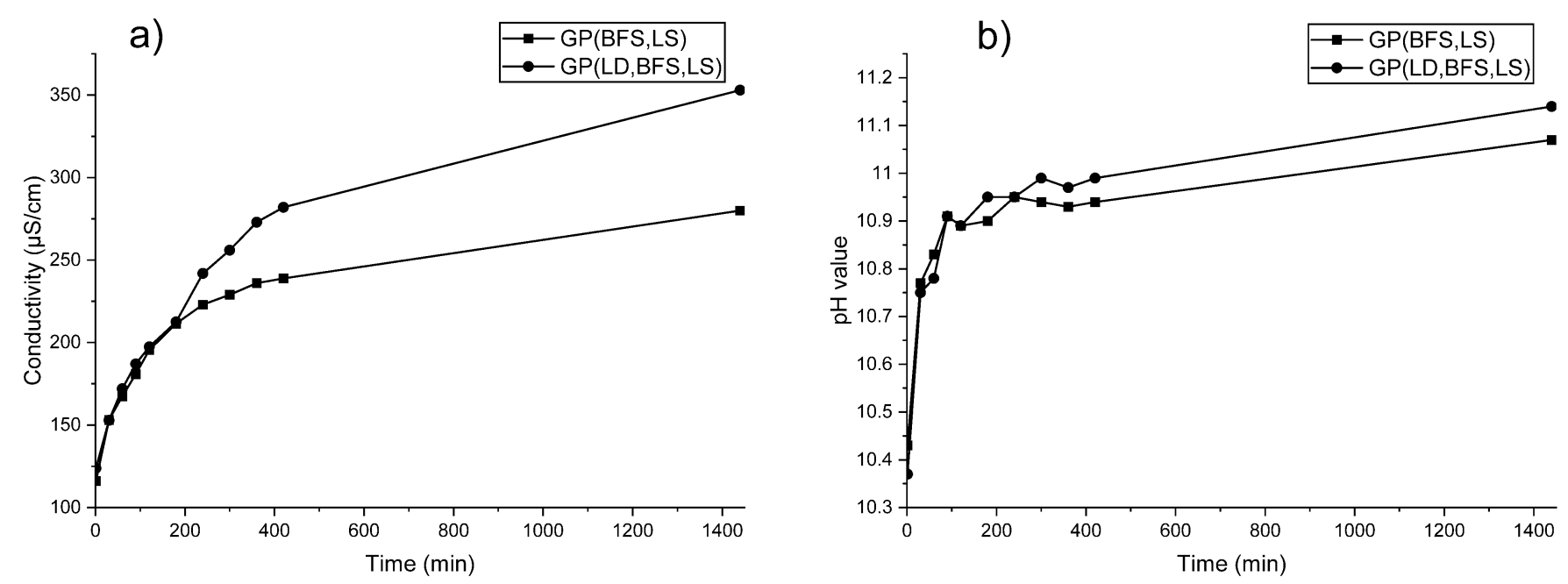

Figure 5. Conductivity value (a) and $\mathrm{pH}$ values (b) of GP (BFS, LS) and GP (LD, BFS, LS) as a function of time during $24 \mathrm{~h}$ leaching.

\subsection{Adsorption-Regeneration Experiments}

During the adsorption-regeneration experiment, the bed height, flow rate, and initial concentration were fixed at values selected from previous studies [21]. A column with $3 \mathrm{~g}$ of slag-based geopolymer with $0.5 \mathrm{~cm}$ bed height and $5 \mathrm{~mL} / \mathrm{min}$ flow rate was used. Adsorption experiments were conducted by using an initial nickel(II) concentration of $50 \mathrm{mg} / \mathrm{L}$. After adsorption, the nickel(II)-loaded geopolymers were regenerated for the 
next cycle. Regeneration and recycling performance are important factors for adsorbents. Moreover, reusing the adsorbent several times reduces the costs and improves the potential of commercial applications [38]. In this study, $\mathrm{NaCl}$ and $\mathrm{NaOH}$ were used as regeneration agents, and the adsorption-regeneration cycle was conducted three times. Sodium-based regeneration agents are suitable in this case because nickel ions' removal is based on ion exchange.

The breakthrough curve describing the effect of the nickel(II) concentration is shown in Figure 6. In the case of GP (LD, BFS, LS), the breakthrough curves became slightly steeper during the three cycles. The mass transfer zone, where the adsorption occurs, did not increase considerably during these three cycles. The adsorption efficiency of GP (LD, BFS, LS) slightly decreased during the adsorption-regeneration cycles (Table 2). The adsorption capacities were $1.34,1.10$, and $0.98 \mathrm{mg} / \mathrm{g}$ for the fresh geopolymer (cycle 1), after first regeneration (cycle 2), and after third regeneration (cycle 3), respectively. This shows the gradual decrease in the adsorption capacity when the geopolymer is reused. For GP (BFS, LS), the same trend of the breakthrough curves and the mass transfer zone occurs as for GP (LD, BFS, LS), except for cycle 1, which differed from this trend. The adsorption capacity increased during the first two cycles from 2.92 to $3.78 \mathrm{mg} / \mathrm{g}$. The reason for this could be that the regeneration solution removed adsorbed nickel and other impurities, which caused better removal efficiency for the next adsorption cycle (cycle 2). In addition, the flow rate varied slightly $(4.9-5.3 \mathrm{~mL} / \mathrm{min})$ during adsorption-regeneration cycles, which might also have some effect on the results. After cycle 2, the adsorption capacity decreased to $3.40 \mathrm{mg} / \mathrm{g}$ (cycle 3), indicating that the removal efficiency of the adsorbent started to decrease. Based on the adsorption capacities, GP (BFS, LS) was a superior adsorbent to GP (LD, BFS, LS), which is also supported by the shapes of the breakthrough curves. In the case of GP (LD, BFS, LS), the saturation was achieved after $20 \mathrm{~min}$, while in the case of GP (BFS, LS), nickel adsorption still slightly continued after $90 \mathrm{~min}$. The exception was cycle 1, which achieved equilibrium after $50 \mathrm{~min}$.

a)

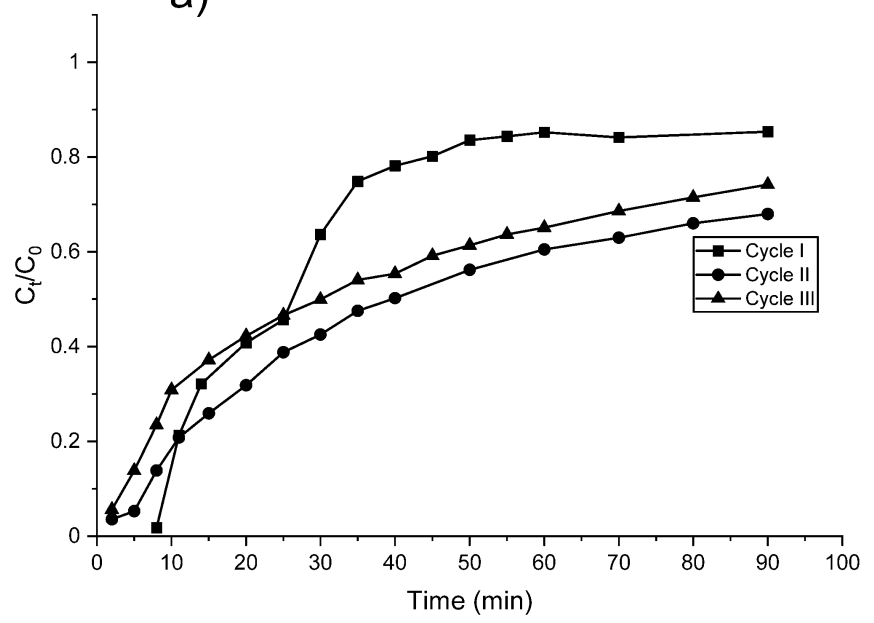

b)

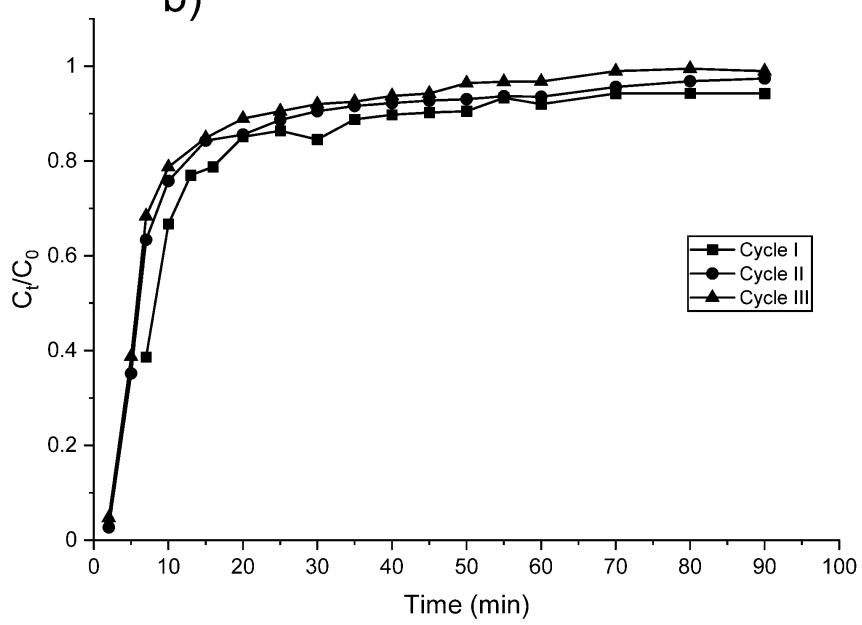

Figure 6. Breakthrough curves for nickel(II) adsorption at $50 \mathrm{mg} / \mathrm{L}$ initial concentration and $5 \mathrm{~mL} / \mathrm{min}$ flow rate: (a) GP (BFS, LS) and (b) GP (LD, BFS, LS). 
Table 2. Parameters of the total uptake of nickel(II) $\left(q_{\text {total }}\right)$, equilibrium nickel(II) uptake $\left(q_{e}\right)$, and total percentage of nickel(II) removal at a fixed-bed height and concentration during three cycles. The bed height $(Z)$ remained almost constant during the three cycles.

\begin{tabular}{cccccc}
\hline Adsorbent & $\begin{array}{c}C_{\mathbf{0}} \\
(\mathbf{m g} / \mathbf{L})\end{array}$ & $\begin{array}{c}Q \\
(\mathbf{m L} / \mathbf{m i n})\end{array}$ & $\begin{array}{c}\mathbf{Z} \\
(\mathbf{c m})\end{array}$ & $\begin{array}{c}q_{\text {total }} \\
(\mathbf{m g})\end{array}$ & $\begin{array}{c}q_{\boldsymbol{e}} \\
(\mathbf{m g} / \mathbf{g})\end{array}$ \\
\hline GP (BFS, LS) & & & & & \\
Cycle I & 50 & 5 & 0.5 & 8.79 & 2.92 \\
Cycle II & 50 & 5 & 0.5 & 11.40 & 3.78 \\
Cycle III & 50 & 5 & 0.5 & 10.25 & 3.40 \\
GP (LD, BFS, LS) & & 5 & & & \\
Cycle I & 50 & 5 & 0.5 & 4.01 & 1.34 \\
Cycle II & 50 & 5 & 0.5 & 3.28 & 1.10 \\
Cycle III & 50 & 0.5 & 2.94 & 0.98 \\
\hline
\end{tabular}

Multiple cycles of this experiment prove the reusability and metal recovery efficiency of the adsorbent. The following results suggest that using a mixture of $\mathrm{NaCl}$ and $\mathrm{NaOH}$ solution enabled separating the nickel(II) ions by using a slag-based geopolymer. Further, the recovery efficiency of the slag-based geopolymer reduced according to the increase in the number of adsorption cycles.

In Table 3, metals' removal with several kinds of adsorbents as a comparison to the materials studied in this paper are presented. Because ion exchange is the main adsorption mechanism, it is meaningful to compare metal cations' removal with the same oxidation number. For example, Li and Champagne (2009) [39] reported $0.55 \mathrm{mg} / \mathrm{g}$ adsorption capacity for nickel(II) removal over mollusk shells.

Table 3. Comparison of adsorption capacity of adsorbents to remove different ions in fixed-bed column. Please note that the unit for $q_{\exp }$ is presented as in original source $(\mathrm{mg} / \mathrm{g}, \mathrm{mmol} / \mathrm{g}$ or meq $/ \mathrm{g}$ (milliequivalents)).

\begin{tabular}{|c|c|c|c|c|c|}
\hline Adsorbent & Removed Ion & $\begin{array}{l}\text { Flow Rate } \\
(\mathrm{mL} / \mathrm{min})\end{array}$ & Bed Height $(\mathrm{cm})$ & $q_{\exp }$ & Reference \\
\hline Vermiculite & $\mathrm{Ag}^{+}, \mathrm{Cu}^{2+}$ & 4 & 3 & $\begin{array}{l}\mathrm{Ag}^{+}: 23.96 \mathrm{mg} / \mathrm{g} \\
\mathrm{Cu}^{2+}: 28.39 \mathrm{mg} / \mathrm{g}\end{array}$ & {$[40]$} \\
\hline Almond shell & $\begin{array}{c}\mathrm{Cr}, \mathrm{Cu}^{2+} \\
\text { (simultaneous } \\
\text { removal) }\end{array}$ & 6.0 & 7.0 & $\begin{array}{c}\mathrm{Cr}: 28.47 \mathrm{mg} / \mathrm{g} \\
\mathrm{Cu}^{2+}: 3.446 \mathrm{mg} / \mathrm{g}\end{array}$ & [41] \\
\hline $\begin{array}{c}\text { Marine algae, } \\
\text { Sargassum filipendula }\end{array}$ & $\mathrm{Ni}^{2+}$ & 4 & 30.5 & $1.350 \mathrm{meq} / \mathrm{g}$ & {$[42]$} \\
\hline $\begin{array}{c}\text { Carboxylated } \\
\text { sugarcase bagasse }\end{array}$ & $\mathrm{Cu}^{2+}$ & 1.4 & 1.66 & $1.00 \mathrm{mmol} / \mathrm{g}$ & [43] \\
\hline $\begin{array}{c}\text { Carboxylated } \\
\text { sugarcase bagasse }\end{array}$ & $\mathrm{Co}^{2+}$ & 1.4 & 1.83 & $0.73 \mathrm{mmol} / \mathrm{g}$ & [43] \\
\hline $\begin{array}{c}\text { Carboxylated } \\
\text { sugarcase bagasse }\end{array}$ & $\mathrm{Ni}^{2+}$ & 1.4 & 0.98 & $0.89 \mathrm{mmol} / \mathrm{g}$ & [43] \\
\hline Mollusk shells & $\mathrm{Cd}^{2+}, \mathrm{Ni}^{2+}$ & 3.4 & 10 & $\begin{array}{l}\mathrm{Cd}^{2+}: 1.6 \mathrm{mg} / \mathrm{g}, \\
\mathrm{Ni}^{2+}: 0.55 \mathrm{mg} / \mathrm{g}\end{array}$ & [39] \\
\hline Natural zeolite & $\mathrm{Cu}^{2+}$ & 3 & 15 & $0.15 \mathrm{mmol} / \mathrm{g}$ & [44] \\
\hline $\begin{array}{l}\text { Geopolymer from fly } \\
\text { ash and metakaolin }\end{array}$ & $\mathrm{Cu}^{2+}$ & 3 & 15 & $0.90 \mathrm{mmol} / \mathrm{g}$ & {$[44]$} \\
\hline GP (BFS, LS) & $\mathrm{Ni}^{2+}$ & 5 & 0.5 & $2.92 \mathrm{mg} / \mathrm{g}$ & This study \\
\hline GP (LD, BFS, LS) & $\mathrm{Ni}^{2+}$ & 5 & 0.5 & $1.34 \mathrm{mg} / \mathrm{g}$ & This study \\
\hline
\end{tabular}




\subsection{Adsorption Kinetics}

To demonstrate the experimental data in the initial part of the breakthrough curves, the Adams-Bohart, Thomas, and Yoon-Nelson models were used. The parameters of each model were determined from the linear plot (data not shown) of Equations (3)-(5), as shown in Table 4. Results showed that all three selected models had relatively high $R^{2}$ values, ranging between 0.855 and 0.987 for GB (BFS, LS) and 0.898 and 0.993 for GP (LD, BFS, LS). The calculated $q_{0}$ values in the Thomas model have a decreasing trend during the three cycles, and the values were the same order of magnitude but a little bit lower than the experimental $q_{e}$ values, as presented in Tables 2 and 4 . Results showed that the $\tau$ values (time for $50 \%$ breakthrough) in the Yoon-Nelson model decreased with an increasing number of cycles. This is because adsorption efficiency decreased slightly during adsorption-regeneration cycles. In the case of GP (LD, BFS, LS), $\tau$ values agreed well with the experimental data (Figure 6) in all three cycles. For GP (BFS, LS), there was slightly more difference between the $\tau$ values and the experimental data. However, all three models were quite suitable for modelling the experimental results.

Table 4. Parameters of the Adams-Bohart, Thomas, and Yoon-Nelson models for nickel(II) adsorption by slag-based geopolymers GP (BFS, LS) and GP (LD, BFS, LS) cycles at a fixed-bed height, concentration, and flow rate.

\begin{tabular}{|c|c|c|c|c|c|c|c|c|c|c|c|}
\hline \multirow[t]{2}{*}{ Adsorbents } & \multirow[b]{2}{*}{$\underset{(\mathrm{mL} / \mathrm{min})}{Q}$} & \multicolumn{4}{|c|}{ Adams-Bohart Model } & \multicolumn{3}{|c|}{ Thomas Model } & \multicolumn{3}{|c|}{ Yoon-Nelson Model } \\
\hline & & $\begin{array}{l}k_{A B} \times 10^{-3} \\
(\mathrm{~L} / \mathrm{mg} \mathrm{min})\end{array}$ & $\begin{array}{c}F \\
(\mathrm{~cm} / \mathrm{min})\end{array}$ & $\begin{array}{c}N_{0} \\
(\mathrm{mg} / \mathrm{L})\end{array}$ & $R^{2}$ & $\begin{array}{l}k_{T H} \times 10^{-3} \\
(\mathrm{~L} / \mathrm{min} \mathrm{mg})\end{array}$ & $\begin{array}{c}q_{0} \\
(\mathrm{mg} / \mathrm{g})\end{array}$ & $R^{2}$ & $\begin{array}{c}k_{Y N} \\
(\mathrm{~L} / \mathrm{min})\end{array}$ & $\tau(\min )$ & $R^{2}$ \\
\hline \multicolumn{12}{|l|}{ GP (BFS, LS) } \\
\hline Cycle I & 5 & 8.61 & 0.0271 & 47.198 & 0.855 & 9.714 & 1.322 & 0.875 & 0.541 & 14.729 & 0.87 \\
\hline Cycle II & 5 & 4.89 & 0.0179 & 28.368 & 0.947 & 5.293 & 1.264 & 0.941 & 0.244 & 15.920 & 0.941 \\
\hline Cycle III & 5 & 5.10 & 0.0223 & 29.152 & 0.978 & 5.853 & 0.987 & 0.985 & 0.274 & 12.099 & 0.985 \\
\hline \multicolumn{12}{|l|}{$\begin{array}{c}\text { GP (LD, BFS, } \\
\text { LS) }\end{array}$} \\
\hline Cycle I & 5 & 2.25 & 0.0311 & 46.684 & 0.898 & 5.460 & 0.713 & 0.953 & 0.279 & 8.275 & 0.953 \\
\hline Cycle II & 5 & 12.95 & 0.0647 & 46.553 & 0.947 & 16.767 & 0.526 & 0.983 & 0.839 & 6.114 & 0.983 \\
\hline Cycle III & 5 & 10.28 & 0.0652 & 50.916 & 0.958 & 14.311 & 0.545 & 0.993 & 0.762 & 5.842 & 0.993 \\
\hline
\end{tabular}

\section{Conclusions}

To conclude this study, the nickel(II) ions were successfully removed from aqueous solution in column studies using slag-based geopolymer adsorbents GP (BFS, LS) and GP (LD, BFS, LS), which were prepared using non-conventionally used slags obtained from the steel industry. The initial nickel(II) concentration in the solution was $50 \mathrm{mg} / \mathrm{L}$ in all experiments. The nickel(II) removal capacity of each adsorbent was studied at $\mathrm{pH} 6$, where nickel(II) solution was passed through the column in which a $0.5 \mathrm{~cm}$ bed height was used. It was observed that this provides the maximum adsorption capacity of $2.92 \mathrm{mg} / \mathrm{g}$ for GP (BFS, LS) and $1.34 \mathrm{mg} / \mathrm{g}$ for GP (LD, BFS, LS). The Adam-Bohart, Thomas, and Yoon-Nelson models fitted well to the experimental data from fixed column experiment results. Thus, the slag-based geopolymer as an adsorbent can be used in wastewater treatment to remove nickel(II) from aqueous solutions.

Author Contributions: Conceptualization, E.S.; methodology, E.S.; software, T.K., H.R. and E.S.; investigation, E.S., T.H. and T.V.; data curation, E.S., H.R., T.K. and S.T.; writing-original draft preparation, E.S.; writing—review and editing, E.S., S.T., H.R., T.K., T.H. and U.L., visualization, E.S., H.R., T.H. and T.K.; supervision, S.T., H.R. and U.L.; project administration, U.L.; funding acquisition, E.S. and U.L. All authors have read and agreed to the published version of the manuscript.

Funding: This research was funded by Maa-ja Vesitekniikan tuki ry. This work was conducted under the auspices of the Waterpro (ERDF project number: A74635, funded by the European Union, European Regional Development Fund and Leverage from the EU and Regional Councils).

Institutional Review Board Statement: Not applicable.

Informed Consent Statement: Not applicable. 
Data Availability Statement: The data presented in this study are available within the article (tables and figures). The data presented in this study are available on request from the corresponding author.

Acknowledgments: The authors would like to thank Jessica Nuorala, Jaakko Pulkkinen, and Elisa Wirkkala for their help in analyzing nickel(II) ions.

Conflicts of Interest: Authors declare no conflict of interest. The funders had no role in the design of the study; in the collection, analyses, or interpretation of data; in the writing of the manuscript, or in the decision to publish the results.

\section{References}

1. Cheng, T.; Lee, M.; Ko, M.; Ueng, T.; Yang, S. The heavy metal adsorption characteristics on metakaolin-based geopolymer. Appl. Clay Sci. 2012, 56, 90-96. [CrossRef]

2. Siyal, A.A.; Shamsuddin, M.R.; Khan, M.I.; Rabat, N.E.; Zulfiqar, M.; Man, Z.; Siame, J.; Azizli, K.A. A review on geopolymers as emerging materials for the adsorption of heavy metals and dyes. J. Environ. Manag. 2018, 224, 327-339. [CrossRef]

3. Ahmed, J.K.; Ahmaruzzaman, M. A review on potential usage of industrial waste materials for binding heavy metal ions from aqueous solutions. J. Water Process. Eng. 2016, 10, 39-47. [CrossRef]

4. Al-Zboon, K.; Al-Harahsheh, M.S.; Hani, F.B. Fly ash-based geopolymer for Pb removal from aqueous solution. J. Hazard. Mater. 2011, 188, 414-421. [CrossRef] [PubMed]

5. Javadian, H.; Ghorbani, F.; Tayebi, H.-A.; Asl, S.H. Study of the adsorption of Cd (II) from aqueous solution using zeolite-based geopolymer, synthesized from coal fly ash; kinetic, isotherm and thermodynamic studies. Arab. J. Chem. 2015, 8, 837-849. [CrossRef]

6. Medpelli, D.; Sandoval, R.; Sherrill, L.; Hristovski, K.D.; Seo, D.-K. Iron oxide-modified nanoporous geopolymers for arsenic removal from ground water. Resour. Technol. 2015, 1, 19-27. [CrossRef]

7. Sarkar, C.; Basu, J.K.; Samanta, A.N. Synthesis of mesoporous geopolymeric powder from LD slag as superior adsorbent for Zinc (II) removal. Adv. Powder Technol. 2018, 29, 1142-1152. [CrossRef]

8. Al-Harahsheh, M.S.; Al Zboon, K.; Al-Makhadmeh, L.; Hararah, M.; Mahasneh, M. Fly ash based geopolymer for heavy metal removal: A case study on copper removal. J. Environ. Chem. Eng. 2015, 3, 1669-1677. [CrossRef]

9. Duan, P.; Yan, C.; Zhou, W.; Ren, D. Development of fly ash and iron ore tailing based porous geopolymer for removal of Cu(II) from wastewater. Ceram. Int. 2016, 42, 13507-13518. [CrossRef]

10. Ge, Y.; Yuan, Y.; Wang, K.; He, Y.; Cui, X. Preparation of geopolymer-based inorganic membrane for removing Ni2+ from wastewater. J. Hazard. Mater. 2015, 299, 711-718. [CrossRef]

11. Luukkonen, T.; Věžníková, K.; Tolonen, E.-T.; Runtti, H.; Yliniemi, J.; Hu, T.; Kemppainen, K.; Lassi, U. Removal of ammonium from municipal wastewater with powdered and granulated metakaolin geopolymer. Environ. Technol. 2018, 39, 414-423. [CrossRef]

12. Sočo, E.; Kalembkiewicz, J. Adsorption of nickel(II) and copper(II) ions from aqueous solution by coal fly ash. J. Environ. Chem. Eng. 2013, 1, 581-588. [CrossRef]

13. Luukkonen, T.; Runtti, H.; Niskanen, M.; Tolonen, E.-T.; Sarkkinen, M.; Kemppainen, K.; Rämö, J.; Lassi, U. Simultaneous removal of $\mathrm{Ni}(\mathrm{II}), \mathrm{As}(\mathrm{III})$, and $\mathrm{Sb}(\mathrm{III})$ from spiked mine effluent with metakaolin and blast-furnace-slag geopolymers. J. Environ. Manag. 2016, 166, 579-588. [CrossRef]

14. Kara, I.; Yilmazer, D.; Akar, S.T. Metakaolin based geopolymer as an effective adsorbent for adsorption of zinc(II) and nickel(II) ions from aqueous solutions. Appl. Clay Sci. 2017, 139, 54-63. [CrossRef]

15. Sarkar, C.; Basu, J.K.; Samanta, A.N. Removal of $\mathrm{Ni}^{2+}$ ion from waste water by Geopolymeric Adsorbent derived from LD Slag. J. Water Process. Eng. 2017, 17, 237-244. [CrossRef]

16. Goretta, K.; Chen, N.; Mora, F.G.; Routbort, J.; Lukey, G.; Van Deventer, J. Solid-particle erosion of a geopolymer containing fly ash and blast-furnace slag. Wear 2004, 256, 714-719. [CrossRef]

17. Provis, J.L.; Van Deventer, J.S.J. Geopolymers. In Geopolymers; Elsevier: Amsterdam, The Netherlands, 2009; pp. 1-464.

18. Ahmaruzzaman, M. A review on the utilization of fly ash. Prog. Energy Combust. Sci. 2010, 36, 327-363. [CrossRef]

19. Lee, N.; Khalid, H.R.; Lee, H. Adsorption characteristics of cesium onto mesoporous geopolymers containing nano-crystalline zeolites. Microporous Mesoporous Mater. 2017, 242, 238-244. [CrossRef]

20. Das, K.K.; Das, S.N.; Dhundasi, S. Nickel, its adverse health effects \& oxidative stress. Indian J. Med. Res. 2008, 128, 412-425. [PubMed]

21. Kapur, M.; Mondal, M.K. Design and model parameters estimation for fixed-bed column adsorption of $\mathrm{Cu}(\mathrm{II})$ and Ni(II) ions using magnetized saw dust. Desalination Water Treat. 2015, 57, 12192-12203. [CrossRef]

22. Runtti, H.; Luukkonen, T.; Niskanen, M.; Tuomikoski, S.; Kangas, T.; Tynjälä, P.; Tolonen, E.-T.; Sarkkinen, M.; Kemppainen, K.; Rämö, J.; et al. Sulphate removal over barium-modified blast-furnace-slag geopolymer. J. Hazard. Mater. 2016, 317, 373-384. [CrossRef]

23. Raval, N.P.; Shah, P.U.; Shah, N.K. Adsorptive removal of nickel(II) ions from aqueous environment: A review. J. Environ. Manag. 2016, 179, 1-20. [CrossRef]

24. Jiang, D.; Yang, Y.; Huang, C.; Huang, M.; Chen, J.; Rao, T.; Ran, X. Removal of the heavy metal ion nickel (II) via an adsorption method using flower globular magnesium hydroxide. J. Hazard. Mater. 2019, 373, 131-140. [CrossRef] [PubMed]

25. Bohart, G.S.; Adams, E.Q. Some aspects of the behavior of charcoal with respect to chlorine. J. Am. Chem. Soc. 1920, 42, 523-544. [CrossRef] 
26. Nguyen, L.H.; Vu, T.M.; Le, T.T.; Trinh, V.T.; Tran, T.P.; Van Tuyen, T. Ammonium removal from aqueous solutions by fixed-bed column using corncob-based modified biochar. Environ. Technol. 2019, 40, 683-692. [CrossRef]

27. Thomas, H.C. Heterogeneous Ion Exchange in a Flowing System. J. Am. Chem. Soc. 1944, 66, 1664-1666. [CrossRef]

28. Yoon, Y.H.; Nelson, J.H. Application of Gas Adsorption Kinetics-II. A Theoretical Model for Respirator Cartridge Service Life and Its Practical Applications. Am. Ind. Hyg. Assoc. J. 1984, 45, 517-524. [CrossRef]

29. Djobo, J.N.; Tchadjié, L.; Tchakoute, H.; Kenne, B.; Elimbi, A.; Njopwouo, D. Synthesis of geopolymer composites from a mixture of volcanic scoria and metakaolin. J. Asian Ceram. Soc. 2014, 2, 387-398. [CrossRef]

30. Huang, Y.; Han, M.; Yi, R. Microstructure and properties of fly ash-based geopolymeric material with 5A zeolite as a filler. Constr. Build. Mater. 2012, 33, 84-89. [CrossRef]

31. Phoo-Ngernkham, T.; Chindaprasirt, P.; Sata, V.; Hanjitsuwan, S.; Hatanaka, S. The effect of adding nano-SiO $\mathrm{O}_{2}$ and nano- $\mathrm{Al}_{2} \mathrm{O}_{3}$ on properties of high calcium fly ash geopolymer cured at ambient temperature. Mater. Des. 2014, 55, 58-65. [CrossRef]

32. Mácová, P.; Sotiriadis, K.; Slí̌̌ková, Z.; Šašek, P.; Řehoř, M.; Závada, J. Evaluation of Physical Properties of a Metakaolin-Based Alkali-Activated Binder Containing Waste Foam Glass. Materials 2020, 13, 5458. [CrossRef] [PubMed]

33. Rasaki, S.A.; Bingxue, Z.; Guarecuco, R.; Thomas, T.; Minghui, Y. Geopolymer for use in heavy metals adsorption, and advanced oxidative processes: A critical review. J. Clean. Prod. 2019, 213, 42-58. [CrossRef]

34. Giannopoulou, I.; Panias, D. Hydrolytic stability of sodium silicate gels in the presence of aluminum. J. Mater. Sci. 2010, 45, 5370-5377. [CrossRef]

35. Zhang, Z.; Wang, H.; Provis, J.L. Quantitative study of the reactivity of fly ash in geopolymerization by FTIR. J. Sustain. Cem. Mater. 2012, 1, 154-166. [CrossRef]

36. Aly, Z.; Vance, E.R.; Perera, D.S.; Hanna, J.V.; Griffith, C.S.; Davis, J.; Durce, D. Aqueous leachability of metakaolin-based geopolymers with molar ratios of $\mathrm{Si} / \mathrm{Al}=1.5-4$. J. Nucl. Mater. 2008, 378, 172-179. [CrossRef]

37. Lancellotti, I.; Kamseu, E.; Michelazzi, M.; Barbieri, L.; Corradi, A.; Leonelli, C. Chemical stability of geopolymers containing municipal solid waste incinerator fly ash. Waste Manag. 2010, 30, 673-679. [CrossRef]

38. Patel, H. Fixed-bed column adsorption study: A comprehensive review. Appl. Water Sci. 2019, 9, 45. [CrossRef]

39. Li, C.; Champagne, P. Fixed-bed column study for the removal of cadmium (II) and nickel (II) ions from aqueous solutions using peat and mollusk shells. J. Hazard. Mater. 2009, 171, 872-878. [CrossRef] [PubMed]

40. Długosz, O.; Banach, M. Sorption of $\mathrm{Ag}^{+}$and $\mathrm{Cu}^{2+}$ by Vermiculite in a Fixed-Bed Column: Design, Process Optimization and Dynamics Investigations. Appl. Sci. 2018, 8, 2221. [CrossRef]

41. Yahya, M.; Abubakar, H.; Obayomi, K.; Iyaka, Y.; Suleiman, B. Simultaneous and continuous biosorption of $\mathrm{Cr}$ and Cu (II) ions from industrial tannery effluent using almond shell in a fixed bed column. Results Eng. 2020, 6, 100113. [CrossRef]

42. Borba, C.; Guirardello, R.; Silva, E.; Veit, M.; Tavares, C. Removal of nickel(II) ions from aqueous solution by biosorption in a fixed bed column: Experimental and theoretical breakthrough curves. Biochem. Eng. J. 2006, 30, 184-191. [CrossRef]

43. Xavier, A.L.P.; Adarme, O.F.H.; Furtado, L.M.; Ferreira, G.M.D.; Da Silva, L.H.M.; Gil, L.F.; Gurgel, L.V.A. Modeling adsorption of copper(II), cobalt(II) and nickel(II) metal ions from aqueous solution onto a new carboxylated sugarcane bagasse. Part II: Optimization of monocomponent fixed-bed column adsorption. J. Colloid Interface Sci. 2018, 516, 431-445. [CrossRef] [PubMed]

44. Rocha, A.C.D.C.; Scaratti, G.; Moura-Nickel, C.D.; Da Silva, T.L.; Vieira, M.G.A.; Peralta, R.M.; Peralta, R.A.; De Noni, A.; Moreira, R.D.F.P.M. Economical and Technological Aspects of Copper Removal from Water Using a Geopolymer and Natural Zeolite. Water Air Soil Pollut. 2020, 231, 1-15. [CrossRef] 